DOI: 10.19085/journal.sijbpg030702

\title{
Food Security in India: Need for Improved Distribution System
}

\author{
Dr. Shivesh
}

Asst. Professor, M.B.A. Agri Business, RGSC, Banaras Hindu University, Varanasi, UP, India.

OScholedge International Journal of Business Policy \& Governance ISSN 2394-3351, Vol.03, Issue 07 (2016) pg102-109.

Published by: Scholedge R\&D Center [www.theSCHOLEDGE.org] [Email: editorial@thescholedge.org]

\begin{abstract}
Security (Food and Human) is one of the major challenges confronting the world today. Food security is inherently interlinked with other current global challenges of economy and climate change. Food security is said to exist when all people, at all times, have physical, social and economic access to sufficient, safe and nutritious food that meets their dietary needs and food preferences for an active and healthy life.
\end{abstract}

Keywords: Food Security, Public Distribution System, Public Procurement, Nutrition

\section{Introduction}

The issue of food security is back on the agenda for developed countries but more so for developing countries. The recent spells of global food price inflation have once again exposed the vulnerability of the population in developing countries, particularly the poor. Among the most affected are the countries in South Asia, which remains the geographical region with the highest level of malnutrition. Within Asia, India is home to the largest number of malnourished persons in the world. While the high levels of malnutrition are worrying, the fact that there has not been any significant reduction in malnutrition in the recent past despite India being the second-fastest growing economy of the world is intriguing. On the other hand, there has been concern about the deterioration in the food security situation in recent years because of a continuous spell of inflation which has remained above $10 \%$ for the last 3 years. The fact that this episode of slow improvement in most nutritional indicatorsand even the worsening of some, including intake indicators-has coincided with the period of the highest-ever growth of the Indian economy is puzzling. It is puzzling also because the most recent period between 2004-2005 and 2009-20103 shows a significant decline in poverty. While at the aggregate level, this may suggest that the growth of the economy has also led to improvements in the incomes of the poor; this is not true when disaggregated at the state level. This shows that there is a very poor correlation not only between the growth rates of state domestic product (SDP) and poverty reduction, but also with relative food 
prices and agricultural growth at the state level. However, further examination suggests that the extent of poverty reduction as well as nutritional improvements may have more to do with policies at the state level, particularly redistributive policies and the governance of public services, including the primary channel of ensuring food security, the Public Distribution System (PDS). It is in this context that a reexamination of the functions of various social safety nets, including those specifically meant for food security, is undertaken. While the main focus will be the PDS, other schemes such as the Integrated Child Development Scheme (ICDS), a scheme for supplementary nutrition for children under 6 and for pregnant and lactating mothers, and the Mid Day Meal Scheme (MDM), a scheme providing free meals to school children, have also contributed in improving the access to and assuring the supply of better food to poor households. The analysis suggests a reversal of the trend of worsening PDS access by the poor after the introduction of the Targeted Public Distribution System (TPDS). The TPDS performs poorly not only in terms of its stated objective of better access to subsidized food for poor households, but also in terms of program implementation, which is marked by leakages and corruption. Precisely because of dissatisfaction with the TPDS, many state governments have undertaken state-specific measures of expanding coverage to universal or quasi-universal access, along with further subsidies to provide cheap food grains. These schemes, initially implemented only in richer states such as Tamil Nadu and Andhra Pradesh, have been adopted by poorer state such as Chhattisgarh and Odisha, which have seen significant poverty reduction between 2004-2005 and 2009-2010. The other states that have made progress toward expanding the coverage are Jharkhand and Bihar. Close scrutiny of the data suggests that the high poverty reduction at the national level is largely because of the significant poverty reduction in states with high poverty incidence, such as Odisha. The analysis also suggests that the high growth of the gross domestic product (GDP) during 2004-2010 may not have been as effective in either reducing poverty or improving access to food as the food security interventions such as the PDS and MDM. This has implications not only for food security for a vast majority of the population but also for poverty reduction.

"Food insecurity exists when all people, at all times, do not have physical and economic access to sufficient, safe and nutritious food to meet their dietary needs and food preferences for an active and health life"

Food and Agricultural

Organisation (1996)

\section{BACKGROUND}

India's population of approximately 1.2 billion is the second largest in the world. Over 70 percent live in rural areas and depend on agriculture, primarily food grains, for their livelihood. With the economic reforms of the 1990s, the contribution of the agricultural sector to gross domestic product (GDP) has fallen to 17 percent in 2009 while that of the services sector increased to over 50 percent. Economic diversification has resulted in significant economic growth in India of the order of 6 to 8 percent during the past decade. 
This positive growth, coupled with decreasing rates of inflation, has helped to raise incomes and to reduce the overall national poverty level from 40 percent in 1994/95 to 26 percent in 2005. However, poverty was higher among the rural population. Poverty is closely related to food inadequacy and the prevalence of undernourishment, which was still at a high level of about 21 percent in 2005-2007. Paradoxically, India is one of the world's highest producers of food grains and has the largest food schemes in the world. These include:

- Entitlement feeding programmes for children under 6 years of age, primary school children and pregnant women;

- Food subsidy programmes such as the targeted public distribution system (TPDS) in Annapurna;

- Employment programmes

- Social safety net programmes such as national age pension and national family benefit scheme.

\section{Urban Food Security}

Summarising, some aspects of the current global context in respect of food security include:

- The slowing down of the growth rate of food production globally, leading to a decline in per capita output of grain between the 1970 s and the first decade of the twenty-first century.

- The impact of policies of economic liberalisation across the world on access to food for the world's poor, including the urban poor.

- The reduced ability/willingness of governments to raise and spend the required amount of resources by way of public investment on rural and agricultural development as well as on urban infrastructure and public health, given the policy framework of far greater reliance on markets and private investments, and a much lesser role for governments.

- The resulting difficulties in tackling problems relating to all three dimensions of food security, namely, availability, access and absorption. While reviewing the urban context in India, the focus has been on the pattern of urbanisation, the growth of the urban economy and urban inequality, the trends in urban poverty, urban livelihoods, employment and unemployment, and the growth of urban slums. All these have a bearing on urban food and nutrition security. The issue of urban food insecurity both at a general level and in the specific context of India today is briefly discussed below. Perhaps the most distinctive feature of the urban food security situation in much of the developing world is the double burden of malnutrition - the simultaneous existence of a large section of the population being undernourished and a smaller (but growing) section suffering from 'over nutrition' - and 
associated morbidity patterns that impose a strain on financial resources available for public spending on health.

\section{Food Availability:}

Sufficient food must be grown to ensure that everyone can be adequately fed. Despite an increase in agricultural production during the post-Green Revolution period, per capita production of all major staples such has declined during the past two decades except for the two most recent years (Figure 1). Furthermore, these crops are subject to high volatility in production due to its monsoon dependence.

Figure 1: Per Capita Production of Major Food Commodities

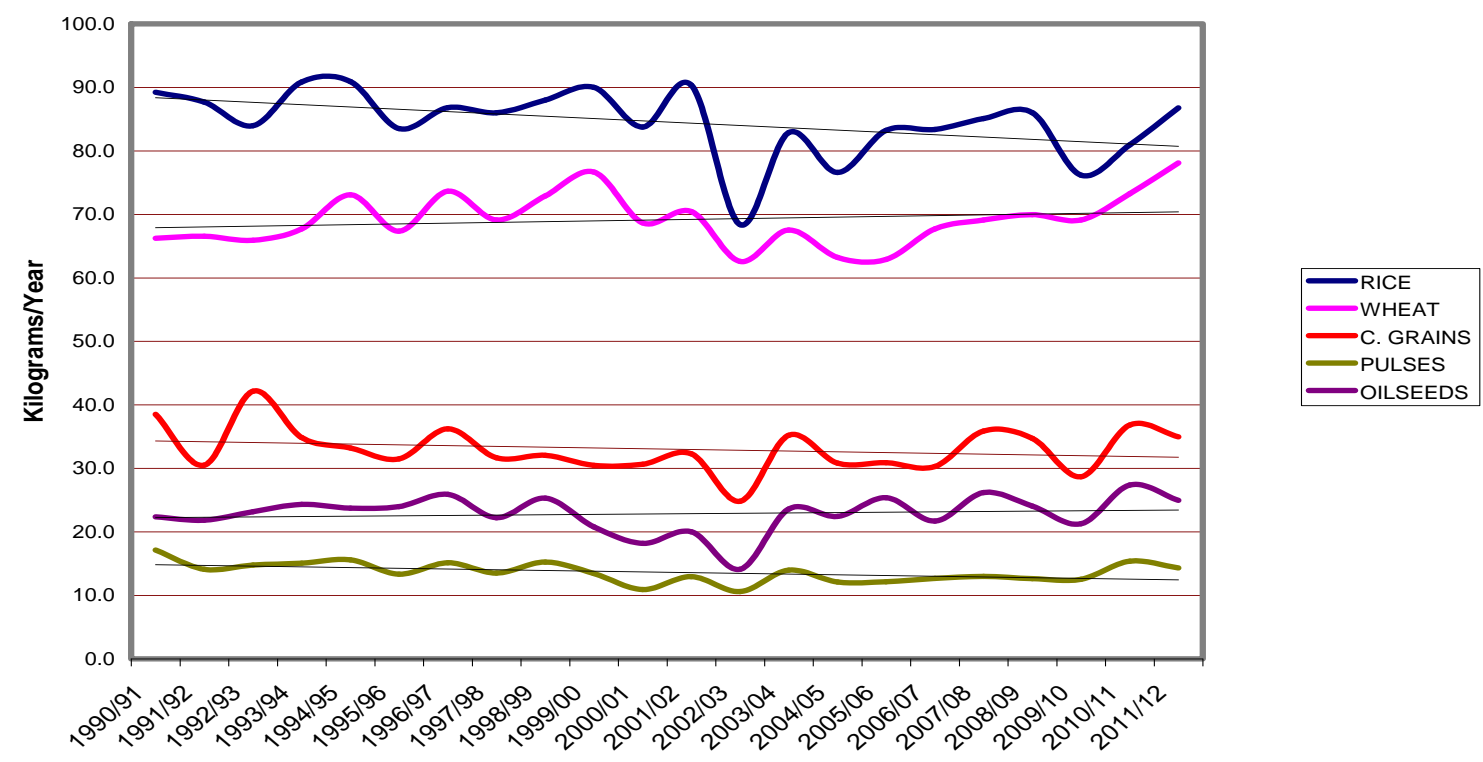

Some of the volatility in production is mitigated through imports, particularly in the case of vegetable oils and pulses.

The per capita consumption of cereals and pulses (major source of protein in Indian diet) has declined over the years, although there was an improvement in the situation in most recent years. The share of non-grain food consumption has not grown to compensate for the decline in grain availability. As a result the overall intake of calories and protein has declined consistently in the average Indian diet over the last three decades, further confirmed by data compiled by the National Sample Survey Organization (Table 1). 
Table 1. Per Capita Intake of Calorie and Protein

\begin{tabular}{|l|c|c|c|c|}
\hline \multirow{2}{*}{} & \multicolumn{2}{|c|}{ Calorie (K cal/day) } & \multicolumn{2}{c|}{ Protein (gm/day) } \\
\cline { 2 - 5 } & Rural & Urban & Rural & Urban \\
\hline 1983 (NSS 38 $^{\text {th }}$ Round) & 2,221 & 2,089 & 62.0 & 57.0 \\
\hline $1993-94$ (NSS 50 ${ }^{\text {th }}$ Round) & 2,153 & 2,071 & 60.2 & 57.2 \\
\hline $1999-2000$ (NSS 55 $5^{\text {th }}$ Round) & 2,149 & 2,156 & 59.1 & 58.5 \\
\hline $2004-05$ (NSS 61 $^{\text {st }}$ Round) & 2,047 & 2,020 & 57.0 & 57.0 \\
\hline $2009-10$ (NSS 66 ${ }^{\text {th }}$ Round) & 2,020 & 1,946 & 55.0 & 53.5 \\
\hline
\end{tabular}

Source: NSS Report No. 540. Nutritional Intake in India, 2009-10

http://mospi.nic.in/mospi_new/upload/nss_rep_540.pdf

\section{Food Accessibility}

The next pillar of food security is access to food - economic and physical -, critical both at the national and household levels. Adequate supply of food alone does not guarantee household level food security. Food access depends on incomes, expenditure, markets and prices in achieving food security objectives. The economic accessibility implies there should be adequate purchasing power in the economy, especially at the lower strata of the society, to buy adequate quantity of food to lead a healthy life. The market and distribution system should be adequate and efficient to ensure that food is available at all marketplaces, both at local and household level. .

Although India has successfully reduced the share of the poor from 54.9 percent of the population in 1973 to around 30.0 percent in 2009 (the latest official data available), thanks to high economic growth in the last decade, more than 350 million people still remain poverty ridden even after six decades of independence.

The Planning Commission's Eleventh Five Year Plan document ${ }^{1}$ states that the number of persons below the poverty line was 301.7 million in 2004 (Table 2). Using the Tendulkar methodology ${ }^{2}$ (which is not directly comparable with the earlier methodology), around 354 million people believed to be below poverty line in 2009-10.

Table 2: India: Population Below the Poverty Line

\begin{tabular}{|l|c|c|c|c|c|c|}
\hline \multirow{2}{*}{} & \multicolumn{3}{|c|}{ \% of People Below Poverty Line } & \multicolumn{3}{c|}{ People Below Poverty Line (million) } \\
\cline { 2 - 7 } & Rural & Urban & Total & Rural & Urban & Total \\
\hline $\mathbf{1 9 7 3 - 7 4}$ & 56.4 & 49.0 & 54.9 & 261.3 & 60.0 & 321.3 \\
\hline $\mathbf{1 9 8 3 - 8 4}$ & 45.7 & 40.8 & 44.5 & 252.0 & 70.9 & 322.9 \\
\hline
\end{tabular}

\footnotetext{
${ }^{1}$ Eleventh Five Year Plan, 2007 - 2102, Volume II (http://planningcommission.gov.in/plans/planrel/fiveyr/11th/11_v2/11th_vol2.pdf)

2 http://planningcommission.nic.in/reports/genrep/Press_pov_27Jan11.pdf
} 


\begin{tabular}{|l|l|l|l|l|l|l|}
\hline 1993-94 & 37.3 & 32.3 & 36.0 & 244.0 & 76.3 & 320.4 \\
\hline 1993-94* & 50.1 & 31.8 & 45.3 & & & \\
\hline 2004-05 & 28.3 & 25.7 & 27.5 & 220.9 & 80.8 & 301.7 \\
\hline 2009-10 * & 41.8 & 25.7 & 37.2 & & & \\
\hline
\end{tabular}

* Tendulkar Commission Methodology

Source: Eleventh Five Year Plan Document, Planning Commission

The report further states that the assumed poverty line (Rs. 356 monthly per capita consumption for rural areas and Rs. 539 for urban areas in 2004-05) in India is much too low, and continues to be based on a consumption basket that is too lean. If the poverty line was higher, the share of population below poverty line would be much greater.

India is home to almost one-third of the world's poor. India currently ranks $65^{\text {th }}$ in the Global Hunger Index compiled by the International Food Policy Research Institute (IFPRI) ${ }^{3}$, even below the neighboring countries such as Sri Lanka and Pakistan and most African countries. The state of food insecurity and hunger in India therefore figures prominently in global food security discussions.

One factor contributing to the food insecurity is the fragmented supply chain and poor infrastructure such as warehouses and cold storage, which adds to the final cost to consumers. The number of intermediaries involved in Indian food chain is large adding to the inefficiency in the food marketing system. Anecdotal evidences suggest that food wastage in the distribution system is very high in India due to poor infrastructure.

\section{Buffer Stocking}

Another major policy devise used by the government to achieve food security is building up and maintaining a buffer stock of wheat and rice. In fact the government's grain import and export decisions are largely governed by the level of stocks in its warehouses and not by the overall domestic grain availability. However, recent experience shows that maintaining a large buffer stock of grains alone is not a sufficient condition to achieve food security. In fact the government policy of maintaining large grain stocks had an adverse impact on food availability. By offering high support prices to farmers the government mopped up a major share of the market surplus thereby significantly lowering the open market availability and contributing to higher open market prices (Table 3). As the government had no efficient mechanism to effectively deliver these stocks to the needy due to flaws in its PDS, this in effect resulted in reduced grain availability and high open market grain prices accentuating food insecurity.

\footnotetext{
${ }^{3}$ http://www.ifpri.org/sites/default/files/publications/ghi12.pdf
} 
Table 3. India: Higher Procurement Prices Leads to Larger Government Procurement

\begin{tabular}{|c|c|c|c|c|c|}
\hline & \multicolumn{2}{|l|}{$\begin{array}{c}\text { Procurement } \\
\text { Million Metric Tonne) }\end{array}$} & \multicolumn{2}{c|}{$\begin{array}{c}\text { Minimum Support Price } \\
\text { (Rs per Tonne) }\end{array}$} & $\begin{array}{c}\text { Food Subsidy } \\
\text { (Billion Rs) }\end{array}$ \\
\hline & RICE & WHEAT & RICE & WHEAT & \\
\hline $2002 / 03$ & $16.4(22.8)$ & $19.0(26.1)$ & 5,500 & 6,200 & 241.8 \\
\hline $2003 / 04$ & $22.9(25.8)$ & $15.8(24.0)$ & 5,500 & 6,300 & 251.8 \\
\hline $2004 / 05$ & $24.7(29.7)$ & $16.8(23.3)$ & 5,600 & 6,300 & 258 \\
\hline $2005 / 06$ & $27.6(30.1)$ & $14.8(21.6)$ & 5,700 & 6,400 & 230.8 \\
\hline $2006 / 07$ & $25.1(26.9)$ & $9.2(13.3)$ & 6,200 & 6,500 & 240.1 \\
\hline $2007 / 08$ & $28.7(29.7)$ & $11.1(14.6)$ & 7,450 & 8,500 & 313.3 \\
\hline $2008 / 09$ & $34.1(34.4)$ & $22.7(28.9)$ & 9,000 & 10,000 & 437.5 \\
\hline $2009 / 10$ & $31.4(35.2)$ & $25.3(31.4)$ & 10,000 & 10,800 & 584.4 \\
\hline $2010 / 11$ & $34.2(35.6)$ & $22.5(25.9)$ & 10,000 & 11,000 & 638.4 \\
\hline $2011 / 12$ & $35.0(33.6)$ & $28.3(32.0)$ & 10,800 & 11,700 & 728.2 \\
\hline $2012 / 13$ & & $38.1(40.6)$ & 12,500 & 12,850 & $* * * 750.0$ \\
\hline
\end{tabular}

Note: Figures in parenthesis shows procurement as a per cent of production

\section{Recent Policy Initiatives and Programs}

The government in recent years has initiated several new programs to achieve and enhance food security. The flagship National Rural Employment Guarantee Program (now renamed as the Mahatma Gandhi National Rural Employment Scheme) ${ }^{4}$, conceived as the largest rural employment guarantee program in the world, legislatively guarantees 100 days of paid employment per year for one member in a rural family. The annual budgetary allocation for this program in IFY 2010-11 is Rs. 401 billion.

The government is now embarking on implementing an ambitious Food Security Act ${ }^{5}$, the main features of which are:

- Legal entitlement to subsidized food grains to be extended up to $75 \%$ of the country's rural population and $50 \%$ of the urban population

- The priority households ( $46 \%$ in rural areas and $28 \%$ in urban areas) to have a monthly entitlement of $35 \mathrm{Kgs}$ (equivalent to $7 \mathrm{Kgs}$ per person) at a subsidized price

- Government of India to specify the criteria for categorization of population into priority and general households

- Legal entitlements for child and maternal nutrition, destitute and other vulnerable Groups

- Reform of the Public Distribution System

\footnotetext{
${ }^{4}$ See: http://nrega.nic.in

${ }^{5}$ http://dfpd.nic.in/fcamin/FSBILL/food-security.pdf
} 
Although the implementation of the provisions of this act will be a challenge considering the ambiguity regarding the number of BPL families, the problem in delivering the grain to targeted families, the additional government subsidy involved, etc., the government is giving topmost priority to this program.

In conclusion we can say that food security in India needs improved distribution system and policy has to change so that food will be available to all people. As in Western countries there is existence of simple regulatory framework which makes the process of food distribution mechanism. It also helps in economic improvement.

\section{References}

Behrman, J., and A. Deolalikar. 1987. Will Developing Country Nutrition Improve with Income? A Case Study for Rural South India. Journal of Political Economy. 95 (3). pp. 492-507.

Bliss, C., and N. Stern. 1978. Productivity, Wages and Nutrition: Part II: Some Observations. Journal of Development Economics. 5 (2). pp. 363-398.

Deaton, A., and J. Dreze. 2009. Nutrition in India: Facts and Interpretations. Economic and Political Weekly. 44 (7). pp. 42-65.

Gaiha, R., R. Jha, and V. Kulkarni. 2010. Prices, Expenditure and Nutrition in India. ASARC Working Paper 2010/15. Australian National University.

Gaiha, R., N. Kaicker, K. Imai, and G. Thapa. 2012. Demand for Nutrients in India: An Analysis Based on the 50th, 61st, and 66th Round of NSS. ASARC Working Paper 2012/08. Australian National University. Government of India, Planning Commission. 1993. Report of the Expert Group on Estimation of Proportion and Number of Poor. Delhi.

Himanshu. 2010. Towards New Poverty Lines for India. Economic and Political Weekly. 45 (1). pp. 38-48.

Himanshu, and A. Sen. 2011. Why Not a Universal Food Security Legislation?

Khera, R. 2011. Revival of the Public Distribution System: Evidence and Explanations. Economic and Political Weekly. 46 (44-45). pp 36-50

Patnaik, U. 2010. A Critical Look at Some Propositions on Consumption and Poverty. Economic and Political Weekly. 45 (6). pp. 74-80.

Pandey, A.P. 2013. Food Security in India: Policies and Challenges, chapter entitled "Contract Farming and Agricultural Development". 